rity, without any pectuniary emolửment to himself, and he pledges himself to the Promoters of the Institution, that the Public shall reap the fruit of their beneficence.

\section{J. C. S S UNDERS,}

Demonstrator of Practical Aatomy, at St. Tromas's Hospital.

24, Ely-place, Holboin.

On this document we shall probably offer a few comments hereafter. On the back of it there was printed the following certificate, signed by the whole of the surgeons and fihysicians attached to Guy's and St. 'Thomas's hosfital :-

"We are of opinior: that the establishment of this charity will prove beneficial, and is therefore worthy of public support; and that the author of the proposal is qualified to secure the accomplishment of its object."

In an advertisement which appeared in The Times, on the 8th of January, 1805, we find the following announcement:-

$$
\text { " LONDON DISPENSARY }
$$

For the relief of the poor, afficted with diseases of the EYE and EAR."

At a meeting of the Committee appointed for the establishment of this Dispensary, held at the City Coffec House, Friday, Jan. -4, 1805, Bevjamin Travers, Esq., in the Chatr,-

It was moved, that the prospectus which lad been published by Mr. SAUNDERs, together witl the above certificate, should be read to the Committee; after which, as the advertisement states, the following resolitions were put and carried unanimously :] -

"That a Dispensary be instituted under the name of the Loxpon Disernsary, for the relief of the poor afficted with diseasses of the EYE and E.AR, where they may apply and obtain advice and medicines gratis."

"That the Dispensary be situated in a central prart of this city, and contain beds for the reception of patients who zndergo the aneration for the cataract, or any other aperation requiring minute care."

"That the Charity consist of a Treasurer, Governors, Secretary, and Medical Officers."

"That Mr. J. C.SAUNoress be appointed the surgeon of the Dispensary, and tlat $D x$. TARRE be appointed physician, in cases requiring medical aid."

"That Mr. R. Batreer be appointed Secretary."
Then follows a list of the Cotnmittee, and the rear is brought up by the signatire of R. Batrlex, Secretary.

The Bustness was so well managed, that the Inftriar Shop was open for the reception of gulls, on the 28th of March, 1805; and three years afterwards, viz. in April, 1808, a formal account of the proceedings of the OphthalmicWarehouse was submitted to the public, in the shape of a pamphlet; the title page of which we will here faithfully sranscribe :-

\section{LONDON INFIRMARY}

\section{FOR CURING}

\section{DISEASES OF THE EXE,}

No. 40, CHARTER-HOUSE, SQUARE, - UNDER THE DIRECTION OF

Mr. SA U N D E R S, Ocoltsist, No. 24, ELY-PLACE;

DR. F A R R E, No. 30, CHARTER-HOUSE SQTARE, CONSULTING PHYSICIAN IN GASES REQUIRING MEDICAL AID;

INSTITUTED, 1804,

OPENED TOR THE CURE OF PATIENTS ON THE 25̃th MARCH, 1805 .

$A$ AND

SUPFORTED BY VOLUNTARY CONTRIBUTIONS,

Is this quackery? Let Dr. FARPe, the friend and coadjutor of the SECRET OPERATOR, answer the question.

This pamphlet contained the following Letter from Mr. SAunders to the Members of the Committee, or rather to the public:

\section{TO THE COMMITTEE.}

Genthamex, $-\Lambda$ s you have resolved to submit this Charity in a regivar form to the notice of the public, it will not be foreign to the design, if I should revert to the circum. stances which attended its origin. On the 1 st of Oetoher, 1804, I published a Proposal for instituting a Dispensary for the relief of the poor, afficted with diseases of the eye and the ear. This Proposal was sanctioned by the testimonials of the physicians and surgeons of St. Thomas's and Guy's Hospitals, where $I$ had then been engaged in pro. fessional studies ten years, during eiglit of 
which I had acted as the teacher of practical anatomy. The plan was immediately encouraged-this Charity was instituted under the name of the London Dispensary for curing Diseases of the Eye and Ear, and opened for the reception of patients on the 25th March, 1805.

Subseqziently to the date of my Proposal, a similar institution, honoured with the royal yatronage, was formed and established in Westminster. Although the prospectus of the Royal Infirmary was not heard of until many months after the publication of my Proposal, yet it must be admitted that that lustitution first appeared before the public in a regular and organised form; and this, which is the original, is consequently considered by all who are unacquainted with the facts, as the copy. Apprehensive of this impression, I immediately eiaimed, by public advertisements, which were never answered, the priority of my proposal.

I shonld be excused for thrus obtruding on your notice, if I sought merely the indulgence of honest pride, by maintaining this just claim to respect; but il shall yet more readily be excused, when you reflect, that if $I$ had abandoned this claim, the public would continue to regard ine as an humble copyist.

In the return which $I$ have now the honour of delivering to you, the cured are arranged under the heads of the diseases with which they were afflicted. In addition to the observations made on the last Report, which are equally applicable to the present, there is one point on which I must beg the indulgence of expatiating, I mean the adaptation of an operation on the cataract to the condition of childhood, by which $I$ have successively cured withont a failure, fourteen persous bom blind, some of them even in infancy, and it has just been performed on an infant only two months old, who is in a state of convalescence. As I reserve for another occasion the communication of the method which I pursue for the cure of very young chillen, $I$ shall no farther compare it with extraction, than by observing, that extraction is wholly inapplicable to children, or only fortuitonsly successful. Those who on all occasions adhere to this operation, and have never turned their thoughts towaris the application of means more suitable to this tender age, have been obliged to wait until the patient has acquired sufficient reason to be tractable-otherwise when they have deviated from this condust, the event has afforded little cause of self-cong ratulation.

How sieat the advantage of an early cure, is a ruestion of no difficult solution. Fyes originally affected witi cataracts contract ain unsteady and $r$ rolling motion, which remains after their removal, and retards, eved when it does not ultimately prevent, the full benefit of the operation. A person cured at a late period cannot overcome this awkward habit by the utmost exertion of reason or efforts of the will. But the actions of the infant are instinctive. Surrounding objects attract attention, and the eye naturally follows them. The management of the eye is therefore readily acquired, his vision rapidly improves, and he will most probably be susceptible of education about the usual period.

I am, Gentlemen, Your obedient servant,

$$
\text { J. C. SAunders. }
$$

Ely Place, March 2.5, 1808.

\section{And in the address of the Committee to}

the public, we find the following paragraphs:

"The Committee avail themselves of the close of the third year, whon experience has displayed the utility of this infirmary, to publish its proceedings to the world. The benevolent will on this occasion participate in their sentiments-satisfaction for the past and anticipation of future success-an antipipation which is founded on the character and conduct of the gentleman from whom the plan of the Charity originated, and to whose skill and personal exertions its usefulness is to be ascribed. Let it not be thought, that in bestowing this just applause, they have exceeded the line of their duty. By diffusing a knowledge of his talents and the application of them, they advance the interests of the Institu. tion, and it is grateful to their feelings to blend distinguished individual merit with the great and general cause of benevolence.

They feel it their indispensable duty to call the public attention to the fact, that the operation on persons born blind with cataracts, has hitherto been deferred until they arrive at an age when reason will teach them the necessity of submission. To Mrr. Saunders belongs the praise of having overcome the difficulty of the case, by an operation which he has peiformed with uniform success on children at various ages, earlier than that at which oculists have been accustomed to operate, and even on an infant only nine months old."

The lines in italics are thus distinguished in the original. In the same pamphlet is published a statement of the Joint Stock Ophthalmic Company's accounts; it does not say by whom they were audited, but doubtless every item was satisfiactory to Mesars. Saunders. Farre, and Battley. 
From 25th March, 1805, to 25th March, 1806.

$\begin{array}{lccc}\text { Dr. } & \text { s. } \\ \text { To amount of Life Subscriptions } & 483 & 0 & 0\end{array}$

To amount of Life Subscriptions 483 o 0 By Cash paid House Rent to MiTo do, of Annual subscriptions

$280 \quad 7 \quad 0$

$763 \quad 7 \quad 0$

\section{7}

To Balance brought down, in the hands of the Treasurer .. 39118 \%

To Lease of the House No. 40, Charter-house-square, value ....... $£^{\prime} 300 \quad 0 \quad 0$

To Fixtures in ditto $118 \quad 0 \quad 0$

To Furniture in do. $40 \quad 0 \quad 0$

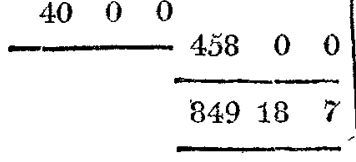

From 25th March, 1806, to 25th March, $180 \%$.

1806.
March 25. To Balance in the hands of Henry Kensington, Esq. 391187 1807.

Maich 25. To Cash paid into the hands of the Treasurer...... $379 \quad 7 \quad 0$

Lease of the House $£ 300 \quad 0 \quad 0$

Fixtures.......... $118 \quad 0 \quad 0$

Furniture ....... 40 o 0 chaelmas last. .............

By do. for Books, Printing, Engraving, Advertising, distributing Letters, and Stamps.. By do. for Medicines and Drugs to Christmas ............. By do. on account of the Lease, and for Household Furniture

By do. Butcher's, Baker's, and Coal Bills, to 18 th Jan. ....

By do. collecting Subscriptions

By do. Housekeeper and Assistant-Gratuity for Service....

By do. Surveyor, Appraiser, and sundry petty Bills.........

By do. William French's Estate to Christmas ............ By do. Taxes, Water Rates, Insurance from Fire, and Lamplighting .............. By Balance in the hands of Henry Kensington, Esq. Treasurer.. 391187 By Arrears of Subscriptions .

By Sundries-Cash adranced by Twenty-seven Gentlemen, to pay for the Lease and Fixtures 40500

By H. Bell, for Half a Year's Rent, due at Lady-day last,

By Cash paid 27 Geritlemen, for Money borrcwed to pay the Lease and Fixtures, 1.5l. each 40500 ByHouse-rent to Michaelmaslast 6500 By Printing, \&c.......... $18120^{\circ}$ By Butcher's, Baker's \& Coal.Bills 601411 By Taxes and Insurance from Fire ................. 1816

By Medicines and Surgeon's Instruments ............. 73110

By collecting Subscriptions.... 1819 j

By Housekeeper and AssistantGratuities for Service ...... $30 \quad 0 \quad 0$

By sundry petty Brils ....... 317

By Balance in the hands of the Treasurer .............. $77^{2} 9$ 
From 25th March, 1807, to 26th March, 1808.

Dr.

Marcl. 95. To Balance in the hands of Henry Kensington, Esq. Treasurer........... $\mathcal{E}$ s. d. 1808.

March 25. To Cash; amount of Subscriptions paid into the hands of the Treasurer.

38540

$462 \quad 13 \quad 5$

1809.

March 25. By House Rent from

7795 Michaelmas 1806, to this day

By Taxes and Insurance from

Fire ..................

By Butcher's, Baker's and Coal bills ................

By Medicines, Surgical Instruments, and Glasses for the patients restored to sight by operations for the Cataract ..

By Printing, Advertising, Books, and Postage ............

By sundry Petty Bills, Carpenter's Work, Blankets, and Household Utensils, \&c. \&c. By Housekeeper and Attendant's Salaries. ............

By Collector for receiving Subscriptions ..............

By Balance in the hands of the Treasurer ..............

$6411 \quad 8$

462135

1808.

March 23. To Balance brought

down...$\ldots \ldots \ldots \ldots$.

ToLease of the House $300 \quad 0 \quad 0$

To Fixtures ...... 118 o 18

To Furniture...... $40 \quad 0 \quad 0$

Enough for the present; the conclusion in our next: mennwhile we hope the Governors will give the foregoing documents an attentive perusal.

IT is with regret that we announce the / would do well to make known their comdeath of Scinpa, formerly Professor of Surgery in the University of Pavia. VAccs Brntixgmizr, or as he was more frequently called, VAcca, died a short time before. Thus, Italy in a short time has lost two of her brightest ornaments in the medical profession. Te are promised some account of the lives of these eminent men, from our Italian correspondent.

We have authority for stating that the DE.D IIorse T.x at St. Bartholomew's Hospital, is neither levied nor sanctioned by the Surgeons and Physicians of that esta blishment. The Rox Carming are the ex. clusive servants of the Goveryors, by whom they are paid. The stulents, therefore, plaint to the Commete.

We continue to receive a vast number of letters, on the subject of the disgraceful TRICK which has been practised on the pupils of St. Bartiolomew's, by the lecturers, in reference to the Demoxsmatioss; and we find that the whole of the blame connected with this transaction, attaches itself to Mr. Abrrnerrry,-Messrs. StixLEY, Worinld, and Sker, being entirely absolved from any impropriety of conduct; irdeed, we lave the best anthority for stating, that the two former gentlemen wore most desirous that those persons should be advertised, who were to give the DerrosSTRITIONS. 